A. Kapiton ${ }^{1}$, O. Diachenko ${ }^{2}$, R. Zakharov ${ }^{3}$, T. Yanchuk ${ }^{4}$

${ }^{1}$ National University «Yuri Kondratyuk Poltava Polytechnic», Poltava, Ukraine

${ }^{2}$ Mariupol State University, Mariupol, Ukraine

${ }^{3}$ Kyiv National University of Trade and Economics, Kyiv, Ukraine

${ }^{4}$ Vasyl Stus Donetsk National University, Vinnytsia, Ukraine

\title{
SYSTEMATIC APPROACH APPLICATION TO THE DEVELOPMENT FOR THE SITE OF UNIVERSITY SCIENTIFIC ACTIVITY
}

\begin{abstract}
The article analyzes a systematic approach to accounting for scientific activities of universities The object of research of the work is chosen to take into account the research activities of teachers of higher education. The subject of the study is the analysis and use of tools for site development on the subject of this problem. The purpose of the authors consider the research, development and implementation of the site of accounting for research activities of teachers of higher education. It is proved that system analysis is based on systemology, principles of cybernetics and modeling and plays the role of a system approach tool based on mathematical analysis and probability theory, discrete mathematics and operations research, which uses modern computer technologies to implement its basic methods and solution's application of applied problems.
\end{abstract}

Keywords: information system, system analysis, system approach, site, scientific activity, institution of higher education.

\section{Introduction}

It is clear that system analysis is a way to study complex objects in order to identify the impact of the relationship of elements and subsystems on the properties of the object as a whole. Researchers claim that the subject of system analysis is a methodology (a set of methodological tools, a system of actions), which is designed to solve the problem (preparation and justification of solutions to study the goal) on the basis of various scientific tools.

System analysis is based on systemology, principles of cybernetics and modeling and plays the role of a system approach tool. In addition, system analysis is based on mathematical analysis and probability theory, discrete mathematics and operations research, and uses modern computer technology to implement its basic methods and solve applied problems [1,2].

An important component of the professional activity of teachers is research, which directs their creative search for the development of new theoretical concepts, effective methods and educational technologies and more. The introduction of the results of research activities of teachers in the practice of higher education allows to raise the level of professional training of future professionals to a qualitatively new level. As you know, in the modern conditions of higher education, teachers have significant opportunities for research with the help of modern information and communication technologies. In each higher education institution there is a research part that monitors the scientific activities of teachers, organizes their tasks and monitors the deadlines.

According to the task, teachers prepare monographs, articles, regulatory and technical documents, participate in inventive activities and more. It is also possible for teachers of other universities of Ukraine and foreign higher education institutions to work together.

To simplify the process of accounting for all types of activities of teachers of higher education, it is neces- sary to create an information system that will optimize, speed up and improve the work of the research part.

\section{Analysis of recent research and publications}

The topic of educational information technologies through the prism of digitalization of scientific activity of the subjects of the educational process by means of information and communication technologies is of interest to many domestic and foreign scientists.

The works of many scientists, including: I. Bloshchynsky, R. Gorbatyuk, R. Gurevych, M. Zhaldak, O.Evzikova, V.Kovalchuk, V.Ognevyuk, I. Osmolovska, V.Parhomenko, I. Pidlasy, N Yu. Ramsky S. Sysoieva, O.Starysh [1-5, 9].

Among foreign scholars are the following: Meg Butler, Michael J. Hannafin, Janette R. Hill, Janet Macdonald and others.

Researchers believe that the modern approach to scientific work should be systematic and cover all aspects of educational and research work in preparing students of different specialties for professional activities, based on the constant development of information technology [3, 4, 6-8].

The system of knowledge acquired while studying at the university is based on previously acquired, preserved knowledge, due to the fact that:

scientific and technological progress is constantly taking place,

the development of educational innovations is mediated by advances in IT,

development of various software products, provision of qualified services educational content for future customers, which is possible only with the use of information and communication technologies becomes important in the system of forming quality knowledge of students.

The problem of development and implementation of the information system of accounting of scientific activity which take place in the institution of higher education is rather actual. 


\section{Main part}

Systematics has always existed, no matter what form of human general property it is - the idea or the objective reality. The concept of systematics arose together with man. Systematics has always been and is one of the methods of science - as for scientists of the past who did not always fully realize that they enjoy it, so for the modern scientists. At first it was conscious systematization of the process of cognition, presentation of knowledge, and therefore discussions on systemic problems first arose in philosophy, logic, mathematics, so one of the objective reasons the emergence of system science is the systematic thinking of man [1].

Information system - a set of organizational and technical means for storing and processing information to meet the information needs of users. Information system - a communication system that provides collection, retrieval, processing and transmission of information. In any information management system, three types of problems are solved:

situation assessment tasks (sometimes called pattern recognition tasks);

problems of situation description transformation (calculation problems, modeling problems);

decision-making tasks (including optimization)[1].

Modern conditions are characterized by the use of highly efficient information systems based on the use of the latest information technologies. Information, especially its automated processing, still remains an important factor in improving the efficiency of any organization. An important role in the use of information is played by the methods of its registration, processing, accumulation and transmission; systematic storage of information and its issuance in the required form; production of new numerical, graphic and other information $[1,3]$. The main purpose of scientific and methodical work of the teacher has a dual nature, namely: provides professional development and scientific and methodological level of teachers, as well as provides the educational process with scientifically sound teaching aids (programs, plans, textbooks and manuals, visual aids, computer programs). Both sides of the main goal are closely interconnected and interdependent. It is primarily about the development of the teacher as a creative person, about switching him from the consumer type to an independent search for methodological solutions, about transforming the teacher into a developer and author of innovative methods and teaching aids that allow them to implement. The difference between scientific and methodical work of teachers from traditional educational and methodical work is not in mastering existing knowledge in science and not in appropriating someone else's teaching experience, but in finding, extracting new knowledge. The pinnacle of professional and personal growth is the teacher's ability to carry out individual research activities, which can be represented by work on a methodological topic and the implementation of dissertation research on the material and basis of the educational institution. Thus, the scientific and methodological work of the teacher is a scientific study, the purpose of which is to obtain their own, i.e. the au- thor's conclusions and results of theoretical and practical nature in the field of teaching a particular discipline and within the chosen topic [3].

This study considers the implementation of the following system of functionality for scientists:

edit your own profiles;

view last year's research reports;

add research and information on inventive activity

to the database of the information system;

enter in the database of graduate students;

edit information about works;

send and receive messages from the administrator.

The stages of project development are usually performed sequentially, so it is extremely important to follow the sequence of stages and understand that any unexpected and uncoordinated changes might significantly affect the efficiency of work. Work on each project should be carried out in strict accordance with the following stages of work on site development.

1. Pre-project preparation. Idea.

Defining the topic of the future site, clarifying the goals and objectives, defining and analyzing the target audience. Competitors analysis. Site structure development - a sketch of the site on paper. Creating a list of future thematic sections.

2. Development of page design.

2.1. Website design concept (creative design). Creative idea, development of the basic graphic concept of site design on the example of the main and secondary pages. Choice of colors, artistic style. Preparation of design layout.

2.2. Technical design. Development of logical and physical structure of the resource. Page layout, layout, navigation elements.

3. Layout. Creating page templates. Checking the correctness of the code. Layout of site pages on the basis of the approved design of standard pages. Collection of pages.

4. Information content of the site. Preparation of text materials. Preparation of graphic materials in raster format, image optimization. Filling pages.

5. Program part of the project.

5.1. Integration of the site with the management system. Nowadays, no modern site can do without a management system, because it is important not only the beautiful outer shell of this site, but also the ability to conveniently work with it. This is especially true for sites with a branched structure and a large amount of data. Its includes: integration with the management system, programming, server settings, project security. Quality control.

5.2. Programming, project launch. At this stage, the functionality that is not included in the standard composition of the control system is being finalized.

6. Testing the site on the Internet. Testing the site for errors and correct operation in browsers.

7. Placing the site on the Internet. Organization of work on placing the project on the Internet. Domain name selection and registration. Choosing a hosting provider, site hosting. Final testing of the site. Training of the client's staff how to work with the site management system (Fig. 1). 


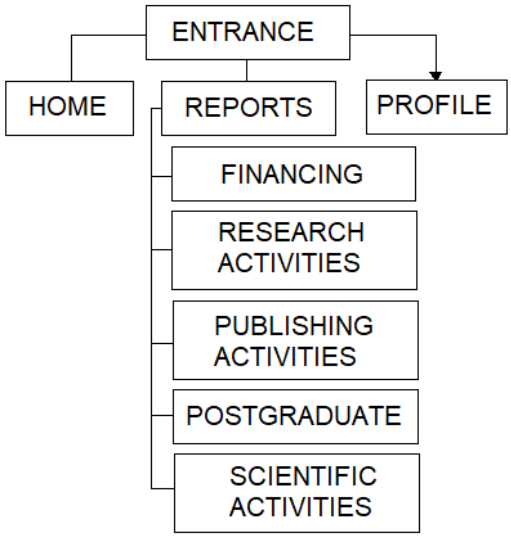

Fig. 1. Site structure for university departments

It is important to test and refine the development. After creating a site, it is spread on the network (Internet), it is necessary to register a domain address for the site and determine the hosting - a place on the server of the provider, where the page will be located. If the site is hosted on the Internet, then before you promote and advertise it, you should check the site for functionality. It is possible that some scripts are executed with errors or important and valuable information is missed somewhere. After the site has been tested and verified for performance, you should ask people who did not participate in the development to review and test the site again. It is possible that certain shortcomings were not noticed, which can be seen by a person who did not participate in the development.
You can also manage a survey: what visitors like or dislike about the site, whether navigation is convenient, and so on.

\section{Conclusions}

The study is based on the concept of systems, where the term "analysis" indicates the nature of the procedure for justifying decisions, which involves: the division of the problem into its components, which are more accessible to solve; use of the necessary methods for solving individual problems; combination of partial solutions into a general one.

Thus, the leading concept of system analysis is a systematic approach. In turn, system analysis is a tool of a systematic approach based on system theory. As the work is complex (the developed site is focused on teachers and employees of the research part of the higher education institution), the implementation of the information system was divided into two parts. In this paper, the implementation of functionalities for entering information about research work of university teachers was considered.

In this information system, the administrator and staff of departments are able to add and edit information about inventive activities, published scientific and technical activities, enter information about graduate students, view last year's research reports, edit their profiles, exchange messages with the administrator. Thus, the introduction of this closed information system allows more efficient and fast accounting of research activities of university teachers.

\section{REFERENCES}

1. Evzikova, O. Google Education Tools URL: http://teachtech.ru/instrumenty-veb-2-0/instrumenty-google-dlyaobrazovaniya.html.

2. Ognevyuk, V., Sysoieva, S. 2015. Training of educational experts in Ukraine: experimental interdisciplinary program. The advanced science journal (6), pp. 98-103.

3. Пархоменко В. 2016. Інформаційна аналітика у сфері науково-технічної діяльності. 224 с.

4. Ковальчук В. В. 2014. Основи наукових досліджень: Навчальний посібник. 208 с.

5. Старіш О. 2018. Системологія . Центр навчальної літератури. 232 с.

6. Donets V., Kuchuk N., Shmatkov S. Development of software of e-learning information system synthesis modeling process. Сучасні інформачійні системи. 2018. Т. 2, № 2. C. 117-121. DOI: https://doi.org/10.20998/2522-9052.2018.2.20.

7. Зиков I. С., Кучук Н. Г., Шматков С. І. Синтез архітектури комп'ютерної системи управління транзакціями е-learning. Сучасні інформачійні системи. 2018. T. 2, № 3. C. 60-66. DOI: https://doi.org/10.20998/2522-9052.2018.3.10.

8. Kovalenko, A. and Kuchuk H. (2018), "Methods for synthesis of informational and technical structures of critical application object's control system", Advanced Information Systems, 2018, Vol. 2, No. 1, pp. 22-27, DOI: https://doi.org/10.20998/2522-9052.2018.1.04

9. Цехмістрова Г. С. Основи наукових досліджень : навчальний посібник / Г. С. Цехмістрова. - К. : Видавничий Дім «Слово», 2003. - 240 с.

Received (Надійшла) 01.10.2021

Accepted for publication (Прийнята до друку) 10.11.2011

\section{Застосування системного підходу до розробки сайта наукової діяльності університету}

\section{А. Капітон, О. Дяченко, Р. Захаров, Т. Янчук}

Анотація. Стаття аналізує системний підхід до розробки сайта наукової діяльності університету. Об'єкт дослідження обрано з урахуванням науково-дослідницької діяльності викладачів вищих навчальних закладів. Предметом дослідження є аналіз та використання інструментів для розробки сайтів на тему даної проблеми. Метою автори вважають дослідження, розробку та впровадження сайту обліку науково-дослідної діяльності викладачів вищих навчальних закладів. Доведено, що системний аналіз базується на системології, принципах кібернетики та моделювання та відіграє роль інструменту системного підходу, заснованого на математичному аналізі та теорії ймовірностей, дискретної математики та дослідження операцій, який використовує сучасні комп'ютерні технології для розв'язку прикладних задач.

Ключ ов і слов а : інформаційна система, системний аналіз, системний підхід, сайт, наукова діяльність, заклад вищої освіти. 